\title{
ARTYKUŁY
}

Jacek Sobczak

jmwsobczak@gmail.com

orcid.org/0000-0002-2231-8824

Uniwersytet Humanistycznospołeczny SWPS

Wydział Prawa

ul. Chodakowska 19/31

03-815 Warszawa

\section{Sztuka a pornografia}

\section{Art and Pornography}

Summary: The freedom of artistic expression is not absolute. Since an artistic activity may threaten someone's dignity, privacy, religious freedom, or freedom of conscience, there may be limits imposed on that right, such as in the case of pornography. Pornography is a phenomenon which has accompanied humanity since the dawn of its history, although it has been considered a crime from the Nineteenth Century onwards. At that time, the evaluation of which communications constituted pornography was changing rapidly. The sexualization of modern culture contributes to the fact that content formerly considered pornographic seems to have no such character today. At the moment, there is no satisfactory uniform definition of pornography either in international law or domestic law. Pornography is often considered dangerous and meriting prosecution on religious grounds as opposed to secular ones. A similar phenomenon occurs in the realm of satire. As a result, both the European Union and Polish jurisdictions have no legal advice on the matter. On the one hand, satirists are allowed to ridicule people's opinions and attitudes, and this constitutes a valid expression of artistic freedom. On the other hand, they should obey certain rules of the critique and refrain from infringing the rights of others. This paper provides some examples of cases supporting the thesis that although there are no explicit European standards on political and religious satire, some general standards in that matter have been established within the European Council legal system.

Keywords: Art, pornography, crimes against sexual freedom 


\section{ARTYKUEY}

Jacek Sobczak

Streszczenie: Działalność artystyczna może rodzić poważne zagrożenia dla innych - naruszając ich godność, prywatność, wolność sumienia i wyznania. Pornografia jest zjawiskiem, które towarzyszy ludzkości od zarania jej dziejów, przy czym od XIX w. jest ona uznawana za przestępstwo. Ocena przekazu jako pornograficzny ulegała zmianom. Seksualizacja kultury przyczynia się do tego, że przekazy uznawane niegdyś z pornograficzne, dzisiaj zdają się nie mieć takiego charakteru. Nie ma zadowalającej definicji pornografii zarówno na płaszczyźnie prawa międzynarodowego, jak i wewnętrznego. Za niebezpieczne uznać należy motywowanie ścigania pornografii względami religijnymi. Z jednej strony satyrycy mogą ośmieszać opinie i poglądy ludzi, z drugiej zaś strony powinni przestrzegać zasad krytyki. W artykule starano się dowieść, że nie istnieją jednak wyraźne europejskie standardy dotyczące przekazu o charakterze erotycznym w europejskich systemach prawnych.

Słowa kluczowe: sztuka, pornografia, przestępstwa przeciwko wolności seksualnej

\section{Uwagi wstępne}

Ekspresja artystyczna towarzyszy - jak się wydaje - człowiekowi od zarania dziejów. Sztuka stanowiła zawsze immanentną część kultury i cywilizacji. Bez sztuki bardzo trudno byłoby zrozumieć nie tylko życie prywatne w poszczególnych epokach, dzieje kultury, ale również historię gospodarczą i polityczną. Sztuka zdaje się nie znać granic geograficznych i chronologicznych. Stale poszerza swój zasięg, obejmując kulturę, religię, systemy polityczne, zawłaszcza gospodarkę, stymulując zachowania rynkowe, tworząc nowe zawody, zapewniając utrzymanie rzeszom pracowników, którzy wprawdzie sami sztuki nie tworzą, ale nią administrują, konserwują jej dzieła, zbierają związane z nią przekazy, handlują nimi. Od początku swojego istnienia sztuka wydaje się być związana z religią, którą częstokroć wyraża, oraz z prawem. To ostatnie stara się z jednej strony zdefiniować pojęcie sztuki, z drugiej zaś wyznaczyć jej granice. Przekonaniu artystów, że sztuka jest wolna i nie podlega żadnej reglamentacji, towarzyszą stale podejmowane próby wyznaczenia dopuszczalnych prawnie sposobów i form ekspresji. W gruncie rzeczy od starożytności po dzień dzisiejszy zauważyć można mniej lub bardziej świadomą walkę o wolność sztuki. Motywy, jakimi kierują się władze publiczne, starając się swobodę tę ograniczyć, mają różne źródła i same przez się zasługują na pogłębioną analizę socjologiczną. Najczęściej wynikają z przyczyn religijnych, osadzone są w pewnych schematach kulturowych, przyzwyczajeniach estetycznych. Według teologów i kapłanów reprezentujących różne religie, sztuka może obrażać uczu- 
cia religijne wiernych, podważać dogmaty, ośmieszać symbole. Zdaniem polityków, zwłaszcza w systemach autorytarnych, sztuka winna służyć państwu, zmierzać do konsolidacji jego obywateli, wyrażać treści aprobowane przez rządzących. W myśl tej koncepcji artysta powinien identyfikować się z reżimem politycznym, służąc mu wiernie i z przekonaniem. Oczywiście są całe rzesze artystów, często niezwykle utalentowanych, którzy gotowi są spełnić zapotrzebowanie czynników religijnych bądź politycznych, tworzyć na zamówienie, które chociaż bywa określane mianem zamówienia społecznego, jest w istocie zamówieniem, które wypływa z kanonów estetycznych przyjętych za właściwe przez zwierzchników politycznych bądź religijnych. Kanony te, z racji posiadanej władzy, potrafią oni narzucić społeczeństwu jako jedynie możliwe do akceptacji ${ }^{1}$.

Zjawisko pornografii ma charakter złożony i wieloaspektowy. Przekaz pornograficzny niejednokrotnie powoduje pewien dysonans u odbiorcy, atakuje jego wrażliwość uwarunkowaną przez normy etyczne bądź obyczajowe. Wielokrotnie prawo arbitralnie wkracza w tę przestrzeń, podejmując próbę ograniczenia wolności sztuki, tworząc w podtekście pewne kanony artystyczne, przesądzając o sprośności lub jej braku w przekazach literackich lub wizualnych. O ile dla tego typu ograniczeń można znaleźć uzasadnienie w sytuacji, gdy u ich podstaw leży ochrona małoletnich, o tyle są całkowicie niezrozumiałe, kiedy dotyczą osób dorosłych i pełnoletnich. Zamiarem piszącego te słowa jest zwrócenie uwagi na to zjawisko, przy czym wobec ram objętościowych rozważań konieczne było w warstwie prawnej ograniczenie się do systemu polskiego.

Twórczość artystyczna charakteryzuje się tym, że nie daje się łatwo wtłoczyć w schematy. Artyści zwykle wyprzedzają swoją epokę, i to czasem o wiele lat. Dzieła, które tworzą, prowokują, częstokroć szokują, godzą w przyzwyczajenia. Artysta wyrażając swoje przeżycia, dając upust żywionym uczuciom, chce jednak zdobyć uznanie społeczeństwa, przekonać do prezentowanej wizji, czasem narzucić swój odbiór rzeczywistości. Poeta czy powieściopisarz może przez lata pisać do szuflady, nie mając szans na publikację swoich dzieł, chociaż dzisiaj, w dobie Internetu możliwe jest udostępnianie takich utworów w formie elektronicznej. Rzeźbiarz, malarz, twórca filmowy pożądają publiczności, w ekshibicjonistyczny sposób obnażają swoje uczucia, z wewnętrznym masochizmem spodziewając się bicza krytyki, licząc jednak, że ich duchowe cierpienie nie będzie daremne, że przekonają do swoich wizji artystycznych.

\footnotetext{
1 Szerzej na ten temat: J. Sobczak, Wolność sztuki, twórczości artystycznej, satyry. Czy istnieje kontratyp sztuki? Regulacje europejskie a rozwiqzania polskiego systemu prawnego, w: J. Jaskiernia (red.), Uniwersalny i regionalny wymiar praw człowieka. Nowe wyzwania - nowe rozwiqzania, t. 3, Wydawnictwo Sejmowe, OWG, Warszawa 2014, s. 360-370; idem, Wolność ekspresji artystycznej. Regulacje europejskie a rozwiqzania polskiego systemu prawnego, „Czasopismo Prawno-Historyczne” 2016, t. 68, z. 2, s. 237-291; M. Gołda-Sobczak, J. Sobczak, Sztuka czy przekaz pornograficzny, w: M.M. Bieczyński, A. Jakubowski (red.), Prawo wobec erotyki w sztuce oraz pornografii, Wydawnictwo Silva Rerum, Wydawnictwo Uniwersytetu Artystycznego, Poznań 2016, s. 271-296.
} 


\section{Pojęcie pornografii}

Obsceniczne obrazy i rzeźby tworzone były już w zamierzchłej przeszłości, a ich przykładem mogą być rysunki naskalne ${ }^{2}$, jednak pornografia jako czyn wyczerpujący znamiona przestępstwa pojawiła się dopiero w epoce nowożytnej. Terminem „pornografia” określa się „pisma, druki, przedstawienia teatralne, filmy, zdjęcia, obrazy, rysunki i inne przedmioty o treści nieprzyzwoitej, obliczone na wywoływanie podniecenia erotycznego u odbiorców"3. Nieco odmiennie tłumaczy ten termin Uniwersalny słownik języka polskiego pod red. Stanisława Dubisza, wskazując, że pornografia to „pisma, filmy, zdjęcia itp., pokazujące nagie ciała (często z odsłoniętymi organami płciowymi), stosunki seksualne w sposób naruszający społeczne normy obyczajowe”. W doktrynie zwykło się odróżniać pornografię „twardą” od „miękkiej”. Pornografia miękka według tego słownika to „pornografia łagodna, pozbawiona agresji i patologii”. Natomiast pornografia twarda to „pornografia pełna agresji, przestawiająca często patologiczne stosunki płciowe"4. Niekiedy wyróżnia się w literaturze dodatkowo pornografię dziecięcą (pedofilię). Wskazuje się zwykle, że określenie „pornografia” pochodzi od greckiego słowa porno, używanego na określenie prostytucji, i słowa graphos - „piszę”. Określenie to nie było jednak znane w klasycznej grece ${ }^{5}$. Od połowy XIX w. termin „pornografia” używany był w nieco innym niż obecnie znaczeniu i określano nim utwory literackie, a także naukowe, które zajmowały się zjawiskiem prostytucji. Odnoszono termin ten także do sztuk teatralnych i sztuk operowych, których tematem były kurtyzany ${ }^{6}$. W lite-

2 Zob. L.M. Nijakowski, Pornografia, historia znaczenie, gatunki, Wydawnictwo Iskry, Warszawa 2010, s. 56-57; E. Saccasyn-Della Santa, Les figures humaines du Paléolithique supérieur eurasiatique, De Sikkel, Anvers 1947. Statuetka pochodzi z Sireuil (zachodnia Francja). Zob. G. Bataille, Łzy Erosa, Wydawnictwo Słowo/obraz Terytoria, Gdańsk 2009, s. 32. Przykładem statuetek odbieranych jako pornograficzne mogą być: Wenus z Lespugue, Wenus z Laussel czy Wenus z Willendorfu.

3 Pornografia [hasło], w: M. Szymczak (red.), Słownik języka polskiego, t. 2, Warszawa 1988, s. 823.

4 Pornografia [hasło], w: S. Dubisz (red.), Uniwersalny słownik języka polskiego, t. 3, Warszawa 2003, s. 387. J.R. Kirk zalicza do pornografii twarde treści, które ukazują akty bestialskie, tortury, oddawanie moczu, kazirodztwo, zniewalanie, gwałt, pseudodziecięcą pornografię oraz sadomasochizm. Do pornografii miękkiej zalicza stosunek dopochwowy między jedną kobietą a jednym mężczyzną (J.R. Kirk, Szkodliwość pornografii, Human Life International-Europa, Gdańsk 1998, s. 3). J. Warylewski zwraca uwagę, że w tym ujęciu brak miejsca na pornografię dziecięcą (J. Warylewski, Pornografia - próba definicji, w: M. Mozgawa (red.), Pornografia, Wolters Kluwer Polska, Warszawa 2011, s. 23). Z.L. Starowicz do pornografii miękkiej zalicza ekspozycję genitalną, praktyki masturbacyjne, stosunki w różnych pozycjach i typowe w danej obyczajowości zachowania seksualne. Jako pornografię twardą traktuje treści ze scenami przemocy, pedofilii i zoofilii (Z. Lew-Starowicz, Seksuologia sadowa, Wydawnictwo Lekarskie PZWL, Warszawa 2000, s. 408-409).

5 Zob. F.S.P. Dufour, Historia prostytucji od czasów najdawniejszych do XX w., t. 1: Czasy przedchrześcijańskie, „Uraeus”, Gdynia 1997, s. 63-131 i n.; C. Reinsberg, Obyczaje seksualne starożytnych Greków, „Uraeus”, Gdynia 1998, s. 68-107.

6 H.N. Parker, Love's body anatomized: the ancient erotic handbooks and the rhetoric of sexulity, w: A. Richlin (red.), Pornography and representation in Greece and Rome, Oxford University Press, Oxford, 1992, s. 90; A. Krawulska-Ptaszyńska, Społeczne skutki upowszechnienia pornografii, „Ruch Prawniczy, Ekonomiczny i Socjologiczny" 1997, z. 1, s. 145. 
raturze podnosi się, że określenia tego użyto prawdopodobnie po raz pierwszy na początku XIX w. w odniesieniu do powieści Justyna czyli nieszczęścia cnoty markiza Donatiena Alphonse'a François de Sade. Zauważyć należy, że de Sade pozostawił trzy wersje Justyny. Pierwsza z nich, Niedole cnoty (Les Infortunes de la vertu), napisana została w 1787 r., a wydana dopiero w 1930 r., druga, zatytułowana Justyna czyli nieszczęścia cnoty, została wydana w 1791 r., trzecia - najobszerniejsza, opublikowana została w 1797 r. pod tytułem Justyna - nowa Justyna ${ }^{7}$. Według Briana McNaira, pornografia $w$ dzisiejszym rozumieniu tego słowa zaistniała w Europie dopiero w 1530 r., wraz opublikowaniem przez włoskiego poetę Pietra Aretina serii sonetów o treści pornograficznej, które rozpowszechniano wraz z 16 śmiałymi ilustracjami Gulio Romano (wł. Giulio Lippi), ucznia samego Rafaela.

W prawie europejskim aż do połowy XVII w. brak było jakiejkolwiek karnoprawnej reglamentacji pornografii. Termin ten zresztą nie występował ani w języku prawnym, ani prawniczym. To, co dzisiaj nosi miano pornografii, określone było dawniej jako treści niemoralne, sprośne, obleśne, obsceniczne, plugawe, nieobyczajne - czyli takie, które naruszają poczucie wstydu i moralności płciowej. Dopiero w 1642 r. w Austrii ordonans Ferdynanda III zakazał sprzedaży przedmiotów sprośnych oraz uznał za przestępstwo drukowanie, sprzedawanie lub rozpowszechnianie książek bądź paszkwili „przeciw religii, służbie króla, dobru Państwa i czystości obyczajów". Nieco później, bo w 1668 r., pojawiła się próba zdefiniowania pornografii, a w zasadzie dzieł obscenicznych, w rozprawie Johannesa Dawida Schrebera z Miśni De libris obsceanis (O księgach nieprzyzwoitych). Stwierdził on, że obscenicznymi są te pisma, których autor „wyraźnie ku nierządnej mowie zmierza, a bezczelne części lub akty wstydliwe lubieżnych ludzi tak opisuje, że niewinne i delikatne uszy odstrasza". Po Austrii podobne zakazy wprowadzono w Anglii w 1727 r. i we Francji w 1797 r. Kodeks karzący Królestwa Polskiego z 1818 r. przewidywał karę zamknięcia w domu poprawy lub aresztu publicznego od trzech miesięcy do roku wtedy, gdy ktoś „publicznie mową, pismem, sztychem lub drukiem dobre obyczaje kazi". W sytuacji, gdy takiego przestępstwa dopuszczał się drukarz lub księgarz, należało orzec przypadek zakazanych towarów, a w razie stwierdzenia, iż po raz trzeci dopuścił się takiego występku, tracił on prawo wykonywania zawodu?.

\footnotetext{
7 Zob. M. Bratuń, Posłowie, w: D.A.F. de Sade, Justyna czyli nieszczęścia cnoty, Wydawnictwo Łódzkie, Łódź 1987, s. 238-239. Por. także K. Matuszewski, Sade. Msza okrucieństwa, Wydawnictwo Słowo/obraz Terytoria, Gdańsk 2008, s. 42-45; M. Praz, Zmysły, śmierć i diabeł w literaturze romantycznej, Wydawnictwo Słowo/obraz Terytoria, Gdańsk 2010, s. 106-111; R. Shattuck, Wiedza zakazana. Od Prometeusza do pornografii, Towarzystwo Autorów i Wydawców Prac Naukowych „Universitas”, Kraków 1999, s. 277 i n.

8 Zob. B. McNair, Mediated Sex. Pornography \& Postmodern Culture, Hodder Education Publishers, Londyn Nowy Jork - Sydney - Auckland 1996, s. 42-43. Zob. także J. Warylewski, Uwagi do art. 202 k.k., w: A. Wąsek, R. Zawłocki (red.), Kodeks karny. Część szczególna, t. 1: Komentarz do art. 117-221, wyd. 4, C.H. Beck, Warszawa 2010, s. 1100-1101; idem, Przestępstwa przeciwko wolności seksualnej i obyczajności. Rozdział XXV Kodeksu karnego. Komentarz, C.H. Beck, Warszawa 2001, s. 189-191.
}

9 Cyt. za: J.Warylewski, Uwagi do art. 202 k.k., s. 1101. 
Próby zdefiniowania pornografii podejmowali zarówno prawnicy, jak i kulturoznawcy, socjologowie i historycy sztuki. W doktrynie podkreśla się, że wszystkie definicje pornografii są w mniejszym lub większym stopniu ułomne ${ }^{10}$. Wydają się wystarczająco precyzyjne w potocznym rozumieniu tego terminu, jednak w obszarze prawa karnego budzą najczęściej wątpliwości. W literaturze, jeszcze w okresie międzywojennym, akcentowano, że powodem kryminalizacji pornografii jest niebezpieczeństwo obrażenia poczucia wstydliwości i publicznej moralności oraz możliwość wywołania podniecenia płciowego ${ }^{11}$. Podkreślano także, że decydujące znaczenie ma zamiar sprawcy, który aby wyczerpać znamiona przestępstwa, winien działać $w$ celu rozbudzenia lub podniecenia pobudliwości płciowej albo oddziaływania na uczucia seksualne ${ }^{12}$. Nieco inaczej spoglądał na problem por-

10 Próby zdefiniowania pornografii dzieli się zwykle na trzy grupy, wyróżniając definicje subiektywistyczno-moralistyczne, obiektywno-pragmatyczne oraz finalistyczne. Definicje subiektywistyczno-moralistyczne opierają się na elemencie zamiaru sprawcy, chcącego aby określoną prezentacją wywołać podniecenie seksualne u odbiorcy. Definicje obiektywno-pragmatyczne, zwane także przedmiotowymi, zasadzają się nie na elemencie zamiaru sprawcy, lecz na obiektywnej treści i na obiektywnych skutkach (domniemanych lub rzeczywistych) określonej prezentacji. Definicje te występowały w wielu odmianach, a mianowicie: anatomicznej, globalnej teorii obiektywistycznej, teorii utraty dystansu, fantazji seksualnej, szczerości, teorii pseudolizmu, teorii ekscytacji erotycznej, agresywnego upublicznienia, wyłącznego zainteresowania, ideologicznej antyseksualnej teorii estetycznej, teorii względnej, ogólnej teorii subiektywnego wyboru, teorii prezentacyjnej i teorii kontekstu. Definicje finalistyczne uzależniają zaliczenie przekazu do pornografii od odbioru adresata przekazu. Zob. M. Filar, Przestępstwa seksualne w polskim prawie karnym, Uniwersytet Mikołaja Kopernika w Toruniu, Toruń 1985, s. 113-118; idem, Pornografia. Studium z dziedziny polityki kryminalnej, Uniwersytet Mikołaja Kopernika w Toruniu, Toruń 1977, s. 30; G. Maroń, Pornografia. Próba sprecyzowania znaczenia terminu, „lus et Administratio” 2005, t. 4, nr 8, s. 160; E. i P. Kronhausen, Pornographie und Gesetz. Die Psychologie des erotischen Realismus u.d. Pornographie, Decker, Stuttgart 1963, s. 124; P. Michelson, An Apology for Porn, w: A.H. Douglas (red.), Perspectives of Pornography, St. Martin's Press, New York 1970, s. 65; S. Sontag, The Pornografic Imagination, w: S. Sontag, Styles of Radical Will?, Dell, New York 1969, s. 35-73. W ostatnim czasie pojawią się definicje eklektyczne, definiujące pornografię przez pryzmat połączonych różnych determinant oraz koncepcje wywodzące się z teorii ochronnych, które do pornografii zaliczają dzieła naruszające dobra objęte ochroną prawną. Wskazuje się, że istotne znaczenie ma podział na „pornografię klasyczną" $i$ "pornografię dewiacyjno-perwersyjną". „Pierwsza z nich stanowi prezentację przejawów seksu niesprzecznych z jego naturalnym biologicznym ukierunkowaniem i w formach wykonawczych tolerowanych społecznie, jeżeliby nawet niektóre z nich uwzględniały wyłącznie warstwę hedonistyczną seksu, z wykluczeniem warstwy prokreacyjnej, lub przybierały formy wyszukane. Zaliczamy tu głównie: prezentację nagości, heteroseksualny petting, w tym także w formie fellatio i conilingus, oraz heteroseksualne stosunki, także w formach akrobatycznych i wyszukanych. Pornografia dewiacyjno-perwersyjna obejmowałaby prezentacje seksu sprzecznego z jego biologicznym ukierunkowaniem oraz seksu w nietolerowanych społecznie (lub także i prawnie) formach, zakładających eksploatację jednego z uczestników stosunku, w szczególności eksploatację polegającą na naruszaniu w związku z aktem seksualnym innych, pozaseksualnych dóbr prawnie chronionych. Zaliczymy tu więc: prezentacje seksu homoseksualnego i lesbijskiego we wszystkich jego wariantach, seks sadystyczny i połączony z gwałtem i przemocą, seks pedofilski, kazirodczy, nekrofilski i zoofilski”. Zob. M. Filar, Pornografia. Studium..., s. 140.

11 L. Peiper, Komentarz do kodeksu karnego, L. Frommer, Kraków 1936, s. 580 i n.

12 S. Śliwiński, Prawo karne materialne. Część szczególna, wyd. 2, Warszawa 1948, s. 136-137. S. Śliwiński wykluczał, aby pornograficzny charakter mogły mieć dzieła dotyczące anatomii ciała ludzkiego o chorobach wenerycznych, prostytucji jako zagadnieniu społecznym, dzieła medycyny sądowej odnoszące się do przestępstw seksualnych, komentarze i opracowania dotyczące przestępstw seksualnych, ilustracje, filmy 
nografii Mieczysław Siewierski, który w treści komentarza do Kodeksu karnego z 1969 r. ${ }^{13}$ zauważył, że pornografia ma na celu podniecenie pobudliwości płciowej, przy czym rozstrzygające znaczenie ma „subiektywny nastrój woli twórcy”, odbijający się w samym dziele ${ }^{14}$. Stanowisko to zdawał się podzielać Marian Filar, podnoszący, że do okoliczności, które mogą decydować o uznaniu prezentacji pewnych treści za pornografię, należy charakter prezentowanych czynności seksualnych, które stają się pornograficznymi, jeżeli w zdecydowany sposób odbiegają od uznawanych standardów społecznych w tym zakresie. Zauważyć przy tym należy, że pojęcie „uznawanych standardów społecznych” jest wyjątkowo nieostre, a same standardy różnią się w zależności od tego, jaka grupa społeczna staje się przedmiotem dociekań. Zmieniają się one także w czasie. Nieostrością także nacechowany jest termin w sposób zdecydowany. Zdaniem M. Filara, pornograficzny charakter mają przekazy, w których przedstawia się przejawy płciowości i życia płciowego człowieka, koncentruje się wyłącznie na technicznych aspektach życia płciowego z oderwaniem od warstwy intelektualnej i osobistej, ukazuje się ludzkie organy płciowe w ich funkcjach seksualnych, w bezpośrednim zetknięciu podczas stosunku, sprowadzając do rejestracji zdepersonalizowanej, odhumanizowanej i akcentującej stronę technologii seksu. Cechy te winny wskazywać jednoznacznie, że jedyną lub główną intencją twórcy było wywołanie podniecenia seksualnego u odbiorcy. Wszystkie te elementy winny wystąpić łącznie. Kryterium pomocniczym jest walor estetyczny. Im jest on niższy, tym bliżej takim treściom do pornografii ${ }^{15}$.

Jarosław Warylewski stoi na stanowisku, że pornografia w wąskim, czyli normatywnym, rozumieniu tego słowa oraz synonimiczne z nią treści pornograficzne, którym to terminem posługuje się chociażby art. 202 § 1-4b Kodeksu karnego z 1997 r. ${ }^{16}$ (dalej: k.k.), to „treści zawarte w dającym się wyodrębnić przekazie informacyjnym (prezentacji) bądź w jego istotnych i odpowiednio spójnych fragmentach, w formie materialnej lub zdematerializowanej, utrwalone za pomocą dowolnego nośnika lub nieutrwalone, charakteryzujące się tym, że przedstawiają w jakiejkolwiek formie autentyczne lub tylko wyobrażone (wykreowane) przejawy połciowości lub życia seksualnego człowieka, w wymiarze ograniczonym (sprowadzonym) do funkcji fizjologicznych oraz aspektów technologiczno-biologicznych"17. Autor

\footnotetext{
i fotografie sporządzone dla celów naukowych, zauważając jednak, że zamieszczenie takowej ikonografii w czasopiśmie powoduje zerwanie związku z celem godziwym. Odnosił to także do twórczości artystycznej.

13 Ustawa z dnia 19 kwietnia 1969 r. Kodeks karny, Dz.U. Nr 13, poz. 94 ze zm.

14 M. Siewierski, w: J. Bafia, K. Mioduski, M. Siewierski, Kodeks karny. Komentarz, wyd. 3, Wydawnictwo Prawnicze, Warszawa 1987, s. 147.

15 M. Filar, Pornografia, „Przegląd Ustawodawstwa Gospodarczego” 1993, nr 8-9, s. 24 i n.; idem, Przestępstwa seksualne..., s. 113.

16 Ustawa z dnia 6 czerwca 1997 r. Kodeks karny, tekst jedn. Dz. U. z 2016 r., poz. 1137 ze zm.

17 J. Warylewski, Pornografia - próba definicji, s. 25. Por. także idem, Przestępstwa seksualne, Wydawnictwo Uniwersytetu Gdańskiego, Gdańsk 2001, s. 254 i n.; idem, Sprośne rysunki, w: J. Zajadło (red.), Fascynujące ścieżki filozofii prawa, LexisNexis, Warszawa 2008, s. 41-55.
} 


\title{
ARTYKUtY
}

\author{
Jacek Sobczak
}

ten zwraca uwagę, że terminem „treści pornograficzne” posługuje się art. 202 k.k., natomiast określenie „pornografia” występuje w ratyfikowanych przez Polskę i obowiązujących umowach międzynarodowych, a także w aktach prawa unijnego. W judykaturze podkreśla się, że termin „treści pornograficzne” użyty w dyspozycji art. 202 k.k. jest pojęciem prawnym, a nie medycznym czy seksuologicznym. Wskazuje się przy tej okazji, że biegły seksuolog posiada wiadomości specjalne w zakresie ustalenia hipotetycznego wpływu danej prezentacji na potencjalnego odbiorcę, w płaszczyźnie jego reakcji emocjonalnych, w tym seksualnych, ale nie jest w stanie zastąpić sądu w ocenie, czy przekaz ma charakter pornograficzny. Podkreślono przy tym, że istotą pornografii jest przekaz określonej idei (treści), a nie jedynie udokumentalizowanej rejestracji określonego zdarzenia faktycznego. Wskazano, że dzieła artystyczne, a także naukowe mogą jednocześnie zawierać treści pornograficzne, a brak karalności produkcji, prezentacji i rozpowszechniania takich dzieł wynika z istnienia pozaustawowego kontratypu sztuki i nauki. Sformułowanie „treści pornograficzne związane z prezentowaniem przemocy”, użyte w art. 202 $\S 3$ k.k., obejmuje swoim zakresem także przedstawianie odegranych przez aktorów scen przemocy, jak też tego rodzaju sceny wytworzone za pomocą różnych innych technik wizualizacji ${ }^{18}$.

Przekonanie o potrzebie kryminalizacji rozpowszechniania, a nawet tworzenia i posiadania przekazów pornograficznych jest dość mocno utrwalone w kulturze europejskiej. Wydaje się być ono zrozumiałe w odniesieniu do dzieci. Trudne natomiast jest do zaakceptowania wobec osób dorosłych. Społeczność międzynarodowa wielokrotnie podejmowała próby ograniczenia pornografii, głównie jednak w odniesieniu do nieletnich ${ }^{19}$.

18 Zob. wyrok Sądu Najwyższego z dnia 23 listopada 2010 r., sygn. akt IV KK 173/10, LEX nr 667510; glosa aprobująca M. Budyn-Kulik (Glosa do wyroku Sądu Najwyższego z dnia 23 listopada 2010 r., IV KK 173/10, LEX/el. 2011).

19 Przykładem może być porozumienie paryskie z 4 maja 1910 r., podpisane przez Polskę w $1922 \mathrm{r}$. (zob. oświadczenie rządowe z 8 września 1922 r. w przedmiocie przystąpienia Rzeczypospolitej Polskiej do Międzynarodowego Porozumienia z dnia 18 maja 1904 roku i do Międzynarodowej Konwencji z dnia 4 maja 1910 roku, podpisanych w Paryżu, dotyczących zwalczania handlu żywym towarem, Dz.U. Nr 87, poz. 783 ze zm.) oraz konwencja z dnia 12 września $1923 \mathrm{r}$. w sprawie zwalczania obiegu i handlu wydawnictwami pornograficznymi, ratyfikowana przez Polskę, Dz. U. z 1927 r. Nr 71, poz. 621. W konwencji tej pozostawiono w gestii każdego państwa ustalenie definicji pojęcia „pornograficzny” (obscène). W systemie unijnym próby ograniczenia pornografii podjęto w wielu aktach normatywnych: w decyzji Rady z dnia 29 maja 2000 r. w sprawie zwalczania pornografii dziecięcej w Internecie (Dz. Urz. UE L 138 z 9.06.2000, s. 1), która odwoływała się do rezolucji Rady i przedstawicieli rządów Państw Członkowskich zebranych w Radzie w dniu 17 lutego 1997 r. w sprawie nielegalnych i szkodliwych treści rozpowszechnianych w internecie (Dz. Urz. UE C 70 z 6.03.1997, s. 1), wspólnego działania Rady 96/700/WSiSW z dnia 29 listopada $1996 \mathrm{r}$. ustanawiającego program zachęty i wymiany dla osób odpowiedzialnych za zwalczanie handlu ludźmi i wykorzystywanie seksualne dzieci (Dz. Urz. UE L 322 z 12.12.1996, s. 7) oraz wspólnego działania Rady 97/154/WSiSW z dnia 24 lutego 1997 r. przyjętego przez Radę na podstawie art. K. 3 Traktatu o Unii Europejskiej dotyczącego działań mających na celu zwalczanie handlu ludźmi i seksualnego wykorzystywania dzieci (Dz. Urz. UE L 63 z 4.03.1997, s. 2). Decyzja z 29 maja 2000 r. uwzględniała też zalecenie przyjęte przez Radę w dniu 24 września 1998 r. w sprawie rozwoju konkurencyjności europejskiego przemysłu 


\section{Kryminalizacja przekazu pornograficznego w polskim systemie prawnym}

W Polsce w ostatnich latach nasiliła się tendencja rozszerzania i kazuistycznego kryminalizowania pornografii. Ścigane jest zarówno publiczne prezentowanie treści pornograficznych w taki sposób, że może to narzucić ich odbiór osobie, która sobie tego nie życzy (art. 202 § 1 k.k.), jak i prezentowanie małoletniemu poniżej lat 15 treści pornograficznych lub udostępnianie mu przedmiotów mających taki charakter albo rozpowszechnianie treści pornograficznych w sposób umożliwiający takiemu małoletniemu zapoznanie się z nimi (art. 202 § 2 k.k. - przepis ten został uchylony przez art. 1 pkt. 4 lit. b ustawy z dnia 4 kwietnia 2014 r., zmieniającej ustawę z dniem 26 maja 2014 r. $^{20}$ ). Ponadto za przestępstwo uznano produkowanie utrwalanie lub sprowadzanie, a także przechowywanie lub posiadanie albo rozpowszechnianie lub publiczne prezentowanie treści pornograficznych z udziałem małoletniego lub treści pornograficznych związanych z prezentowaniem przemocy lub posługiwaniem się zwierzęciem (art. 202 § 3 k.k.) ${ }^{21}$. Wypada w tym miejscu zauważyć, że literalna językowa wykładnia tego przepisu mogłaby zaprowadzić na ławę oskarżonych tych, którzy w domowych bibliotekach przechowują dramat Romeo i Julia Williama Shakespeare'a, Lolitę Vladimira Nobokova czy Justynę Markiza de Sade, zważywszy że wobec mało precyzyjnego pojęcia pornografii dla niektórych przedstawicieli organów ścigania mogłoby się okazać ważne to, że zarówno Julia, jak i Lolita to z dzisiejszego punktu widzenia nieletnie, a w dziele Markiza de Sade czytelnik epatowany jest stosowaniem przemocy. Przestępstwem jest także utrwalanie treści pornograficznych z udziałem małoletniego poniżej lat 15 (art. 202 § 4 k.k.) oraz sprowadzanie, przechowywanie lub posiadanie takich treści z udziałem małoletniego poniżej lat 15, a także produkowanie, rozpowszechnianie, prezentowanie, przechowywanie lub posiadanie treści pornograficznych przedstawiających wytworzony lub przetworzony wizerunek małoletniego uczestniczące-

usług audiowizualnych i informacyjnych przez wspieranie krajowych programów ramowych w celu zapewnienia skutecznego i porównywalnego poziomu ochrony nieletnich i godności ludzkiej (Dz. Urz. UE L 270 z 7.10.1998, s. 48). W dyrektywie ramowej Rady 2004/68/WSiSW z dnia 22 grudnia 2003 r. dotyczącej zwalczania seksualnego wykorzystywania dzieci i pornografii dziecięcej (Dz. Urz. UE L 13 z 20.01.2004, s. 44) zdefiniowano pornografię dziecięcą. Definicja ta została uzupełniona przez dyrektywę Parlamentu Europejskiego i Rady 2011/92/UE z dnia 13 grudnia 2011 r. w sprawie zwalczania niegodziwego traktowania w celach seksualnych i wykorzystywania seksualnego dzieci oraz pornografii dziecięcej, zastępującą decyzję ramową Rady 2004/68/WsiSW (Dz. Urz. UE L 335 z 17.12.2011, s. 1), w art. 2c (J. Warylewski w swoim niezwykle ważnym i potrzebnym studium mylnie stwierdza, że definicja ta znajduje się $w$ art. $2 \mathrm{~b}-\mathrm{J}$. Warylewski, Pornografia - próba definicji, s. 25). Tytuł dyrektywy został zmieniony przez sprostowanie z dnia 21 stycznia 2012 r. (Dz.U. L 18 z 21.01.2012) - zmieniono numer dyrektywy z 2011/92/UE na 2011/93/UE.

20 Ustawa z dnia 4 kwietnia 2014 r. o zmianie ustawy Kodeks karny oraz niektórych innych ustaw, Dz.U. poz. 538.

21 Zob. J. Warylewski, Pornografia, w: idem (red.), Przestępstwa przeciwko dobrom indywidualnym, C.H. Beck, Instytut Nauk Prawnych PAN, Warszawa 2012, s. 809-882; idem, w: R.A. Stefański (red.), Kodeks karny. Komentarz, wyd. 2, Warszawa 2015, s. 1266-1278. 


\title{
ARTYKUtY
}

\author{
Jacek Sobczak
}

go w czynności seksualnej (art. 202 § 4b k.k.). Rzeczywiście groźnym zjawiskiem jest przestępstwo z art. 191a k.k. ${ }^{22}$, polegające na utrwalaniu wizerunku nagiej osoby lub osoby w trakcie czynności seksualnej przy użyciu wobec takiej osoby przemocy, groźby bezprawnej lub podstępu albo na rozpowszechnianiu takiego wizerunku bez zgody takiej osoby ${ }^{23}$.

Przyznać należy, że Kodeks karny kryminalizuje w pierwszym rzędzie wszelkie działania odnoszące się do pornografii z udziałem małoletniego. Dla purytanów, a tych przecież w społeczeństwie nie brakuje, może jednak okazać się pornografią obraz przestawiający nagiego amorka czy aniołka z zaznaczonymi męskimi genitaliami. Historia ludzkości w ogólności, a historia sztuki w szczególności, zna przecież przykłady zasłaniania brązowymi liśćmi klonowymi (wcale nie figowymi) genitaliów męskich na rzeźbach antycznych bądź renesansowych czy zamalowywania takich przekazów nawet na obrazach uznanych mistrzów. W dużej mierze ściganie pornografii zdaje się być uwarunkowane religijnie, zwłaszcza przez trzy główne religie monoteistyczne, których duchowni uznają tego rodzaju przekazy za wyjątkowo grzeszne, negując to, że człowiek w swojej cielesności stworzony

22 Jak wskazuje M. Mozgawa, występek ten, pomieszczony w rozdziale przestępstw przeciwko wolności, winien znaleźć się w ramach rozdziału Kodeksu karnego grupującego przestępstwa przeciwko wolności seksualnej i obyczajności, gdyż dobrem chronionym jest w tym przepisie obyczajność, intymność i prywatność człowieka (M. Mozgawa, Przestępstwa przeciwko wolności, w: idem (red.), Kodeks karny. Praktyczny komentarz, Wolters Kluwer Polska, Warszawa 2010, s. 391). Zob. także W. Wróbel, Opinia prawna o rządowym projekcie ustawy o zmianie ustawy - Kodeks karny, ustawy - Kodeks postępowania karnego, ustawy - Kodeks karny wykonawczy, ustawy - Kodeks karny skarbowy oraz niektórych innych ustaw, Warszawa 28.01.2009 r., druk sejmowy nr 1394.

23 B. Filek, Wizerunek nagiej osoby jako znamię przestępstwa z art. 191a § 1 k.k., „Prokuratura i Prawo” 2012, nr 7-8, s. 61-77. Stanowisko to, wypracowane przez M. Mozgawę (red.), Kodeks karny. Praktyczny..., s. 391, akceptuje J. Kosonoga, wskazując, że z treści przepisu art. 191a § 1 k.k. wynika, że w pojęciu nagości chodzi o intymne części ciała (zob. J. Kosonoga, Karnoprawna ochrona intymnego wizerunku osoby, „Studia i Analizy Sądu Najwyższego" 2011, t. V, s. 224). Zdaniem B. Fileka, wizerunek osoby na fotografii przedstawiający ją bez ubrania, ale od pasa do głowy włącznie, nie będzie stanowił przedmiotu czynności wykonawczej czynu zabronionego $z$ art. 191a § 1 k.k. Ten ostatni autor wyraża także pogląd, że zakresu pojęcia wizerunku osoby należy wyłączyć wizerunek nagich zwłok ludzkich. To ostatnie stanowisko wydaje się dość dyskusyjne, zob. B. Filek, Wizerunek nagiej osoby jako znamię przestępstwa z art. 191 a $§ 1$ k.k., „Prokuratura i Prawo" 2012, nr 7-8, s. 61 i n. Pogląd ten podziela R. Krajewski, zauważając, że gdyby doszło do utrwalania i rozpowszechniania obrazu nagich zwłok człowieka, to w grę wchodziłaby odpowiedzialność za znieważenie zwłok z art. 262 § 1 k.k. (zob. R. Krajewski, Przestępstwo utrwalania i rozpowszechniania wizerunku osoby nagiej lub osoby w trakcie czynności seksualnej, „Prokuratura i Prawo” 2012, nr 5, s. 20-40). R. Krajewski wskazuje także, że pojęcie „osoba naga” dotyczy różnych postaci nagości w rozmaitych kontekstach, zauważając jednak, że nie można popadać w tym zakresie w jakąkolwiek przesadę. Wizerunkiem osoby nagiej, jego zdaniem, będzie sytuacja, gdy taka osoba znajduje się in puris naturalibus, a także wówczas, gdy widać jej narządy płciowe, pośladki oraz piersi (u kobiety), choć - jak przyznaje ten autor - w tym zakresie mogą zachodzić pewne wątpliwości (zob. R. Krajewski, op. cit., s. 20-40; J. Sobczak, M. Gołda-Sobczak, Prawo do informacji a utrwalanie wizerunku osoby nagiej bez jej zgody, w: J. Sobczak, W. Machura (red.), Etyka w mediach, vol. 8: Kodyfikacja czy modyfikacja norm, Wydawnictwo Naukowe Scriptorium, Poznań - Opole 2011, s. 49-58. 
został przez Boga na jego obraz i podobieństwo ${ }^{24}$. Zauważyć przy tym wypada, że przekaz literacki, nawet najbardziej wyuzdany i obsceniczny, a także obrazy i rzeźby nie pociągają dziś najczęściej za sobą oskarżeń o pornografię. Organy ścigania i opinia publiczna dostrzegają pornografię głównie - jeśli nie wyłącznie w treściach serwowanych filmów i przekazach internetowych.

\section{Kultura wobec zjawiska pornografii}

Wytyczenie granicy między pornografią a sztuką nie jest łatwe do określenia, a być może nawet niemożliwe. Zmienia się bowiem zarówno wrażliwość twórcy, jak i odbiorców. Zmieniają się nastawienia do przedstawienia nagiego ciała, stosunku seksualnego, miłości, małżeństwa, erotyzmu i seksualizmu, rozumianych jako zjawiska społeczne. Pomyślane jako obsceniczne rysunki z Pompei, zachowane dzięki wybuchowi wulkanu, uchodzą dziś za dzieła sztuki, prezentowane w poważnych wydawnictwach, podobnie jak malowane greckie wazy i amfory, wystawiane w szacownych muzeach, prezentowane tak jednak, aby ukryć obrazy stosunków homoseksualnych i członków męskich w wzwodzie ${ }^{25}$. Skandalizujące niegdyś opinie publiczną obrazy Édouarda Maneta z lat 60. XIX w., np. Śniadanie na trawie (1963) czy Olimpia (1865), podobnie jak pełne erotyzmu rzeźby Auguste’a Rodina, uznawane są przez dzisiejszych odbiorców za pozbawione jakichkolwiek związków ze sferą erotyczną i odbierane jako szacowne, choć nieco nudne obiekty muzealne. Warto jednak zauważyć, że historycy sztuki nawet w słynnej rzeźbie Gian Lorenza Berniniego Ekstaza Świętej Teresy dopatrują się przedstawienia orgazmu²6. Odróżnienie sztuki od erotyzmu jest więc niezwykle trudne ${ }^{27}$. Niemniej warto zauważyć, że człowiek poszukuje treści erotycznych, obscenicznych, a nawet pornograficznych. Powody tych poszukiwań są różnie interpretowane, zarówno na gruncie seksuologii, psychologii, jak i historii sztuki. Nie neguje się jednak faktu, że zapotrzebowanie na tego rodzaju przesłania istnieje ${ }^{28}$.

Popularność pornografii rośnie, a jej znaczenie w kulturze jest coraz większe. Dostarcza ona wzorów dla życia intymnego, przez co staje się ono wprost porno-

24 D. Øistein Endsjø, Seks a religia. Od balu dziewic po święty seks homoseksualny, Czarna Owca, Warszawa 2011, s. 15-18 i 395-416; R. Tannahill, Historia seksu, Wydawnictwo Aletheia, Warszawa 2013, s. 135-164 i $329-332$.

25 W kwestii estetyki przedstawień zob. chociażby U. Eco (red.), Historia piękna, Dom Wydawniczy Rebis, Poznań 2005, s. 154-175.

26 E. Lucie-Smith, Erotism in Western Art, Oxford University Press, London 1972, s. 82; por. także K. Piwocki, Dzieje sztuki w zarysie, t. 2: Od wieków średnich do końca XVII w., Arkady, Warszawa 1977, s. 184. Zob. także P. Krakowski, Z rozważań nad sztuką erotyczną, w: T. Hrankowska (red.), Sztuka a erotyka. Materiały z Sesji Stowarzyszenia Historyków Sztuki, Łódź, listopad 1994, Arx Regia, Warszawa 1995, s. 13-25.

27 Zob. G. Bataille, Erotyzm, Wydawnictwo Słowo/obraz Terytoria, Gdańsk 1999, s. 140.

28 Zob. idem, Historia erotyzmu, Wydawnictwo Aletheia, Warszawa 2008, s. 227 i n. 


\title{
ARTYKUtY
}

\author{
Jacek Sobczak
}

graficzne ${ }^{29}$. Wraz z rozwojem środków przekazu, zmianami technologicznymi pornografia przestała być obrazem olejnym, akwarelą, grafiką, rysunkiem, ewentualnie przesyconą erotyzmem rzeźbą figuralną, stając się fotografią, obiektem przekazu filmowego czy często bardzo osobistego przesłania internetowego. Linda Williams stwierdza, że dyskusja na temat ekstremalnych i brutalnych treści zawartych w pornografii napędzana jest przez dwie obawy. Pierwsza z nich koncentruje się na tym, że osoby, których ciała zostały wykorzystane do nakręcenia obscenicznych, sprośnych scen, mogły zostać skrzywdzone. Druga z tych obaw sprowadza się do twierdzenia, że skrzywdzeni zostają odbiorcy ${ }^{30}$. Zauważa się także, że wraz z rewolucją wideo i interaktywnymi grami komputerowymi pornograficzne ruchome obrazy przeniosły się z wielkich ekranów na małe ekrany telewizorów i z publicznych kin do prywatnych domów ${ }^{31}$.

Fakt, że Internet wydaje się zapewniać tak pożądaną anonimowość, a jednocześnie gwarantuje dostęp do treści, które w realnej rzeczywistości wydawać by się mogły trudno dostępne, a co najmniej wymagające ujawnienia tożsamości (co dla wielu odbiorców bywa trudne bądź krępujące), spowodował, że właśnie w Internecie współczesny człowiek poszukuje przekazów z obszaru erotyki i seksu ${ }^{32}$. Jest to ubocznym skutkiem pojawienia się nowych koncepcji seksualności, feminizmu i teorii queer ${ }^{33}$. Nie przeczy temu fakt, iż seks, który od końca lat 60 . na stałe przeniknął do kultury masowej, stał się przedmiotem naukowych, popularnonaukowych i publicystycznych rozważań ${ }^{34}$. Bardziej plastyczny i dosłowny przekaz internetowy wypiera w doskonały sposób to, co przekazywała literatura i sztuki

29 W. Klimczyk, Erotyzm ponowoczesny, Towarzystwo Autorówi Wydawców Prac Naukowych Universitas, Kraków 2008, s. 21-22.

30 L. Williams, Hard Core. Władza, przyjemność i „szaleństwo widzialności”, Wydawnictwo Słowo/obraz Terytoria, Gdańsk 2010, s. 201-206; W. Klimczyk, op. cit., s. 196-227. Zob. także D.B. Sova, 125 zakazanych filmów. Historia cenzury w kinie, Świat Książki, Warszawa 2006, passim; A. Bazin, Ontologia obrazu fotograficznego, w: idem, Film i rzeczywistość, Wydawnictwa Artystyczne i Filmowe, Warszawa 1963, s. 14 i n.

31 L. Williams, op. cit., s. 322. Zob. eadem, Seks na ekranie, Wydawnictwo Stowo/obraz Terytoria, Gdańsk 2013, passim.

32 Jako przyczyny sięgania po erotykę w sieci wskazuje się chęć autoprezentacji, upublicznienia swoich doświadczeń i przeżyć seksualnych, realizację potrzeb ekshibicjonistycznych. Widzi się w tym także sposób kompensowania niepowodzeń w realnym świecie. Czasem podnosi się, że strony o zawartości erotycznej służą także celom praktycznym, stanowiąc formę pozyskania sponsora lub partnera seksualnego. Motywem zakładania takich stron mogą być też względy finansowe - uzyskiwanie dochodów z opłat pobieranych za udostępnienie zdjęć, filmów czy przekazów. Internetowe sklepy z akcesoriami seksualnymi zapewniają anonimowość, eliminując lub ograniczając zażenowanie związanie z takimi zakupami (I. Ślęzak, Seks i erotyka w sieci, czyli czego poszukuja internauci, w: M. Sokołowski (red.), Oblicza Internetu. Opus Universale. Kulturowe, edukacyjne i technologiczne przestrzenie Internetu, Wydawnictwo Państwowej Wyższej Szkoły Zawodowej, Elbląg 2008, s. 148-151).

33 Z. Melosik, Ciało, tożsamość, władza. Teksty kulturowe jako konteksty pedagogiczne, Edytor, Poznań - Toruń 1996, passim; J. Mizielińska, Płeć, ciało, seksualność. Od feminizmu do teorii queer, Towarzystwo Autorów i Wydawców Prac Naukowych Universitas, Kraków 2006, s. 63-74 i 163-178.

34 W. Klimczyk, op. cit., s. 160-170. 
plastyczne ${ }^{35}$. W dużej mierze były to jednak dzieła trudno dostępne dla przeciętnego odbiorcy. Drogą internetową udostępnia się filmy o charakterze erotycznym, często obsceniczne i niedopuszczone w wielu krajach do sal kinowych ${ }^{36}$.

Nie da także zaprzeczyć, że zarówno treści pornograficzne, jak i te, które nazywamy tylko erotycznymi, w dużej mierze bazują na nagości, na obrazie nagiego ciała człowieka, zwłaszcza kobiety w trakcie aktu seksualnego. W literaturze podkreśla się, iż sama nagość przybliża odbiorcę do odpychającego centrum erotyzmu, aczkolwiek nie zawsze kojarzy się i nie musi kojarzyć się z nieprzyzwoitością aktu płciowego ${ }^{37}$. Wynalazek fotografii w znaczącym stopniu wpłynął na rozpowszechnienie pornografii przez, jak stwierdza się $w$ literaturze, naiwny realizm towarzyszący zdjęciom, które odnosiły się do sytuacji niedostępnych codziennemu oglądowi, a nie dość realistycznie oddawanych poprzez obrazy i ryciny ${ }^{38}$. Zdjęcia nagich postaci zwróciły uwagę na konieczność określenia granic między erotyką a pornografiąi ${ }^{39}$. Jeszcze większy wpływ na rozwój zjawiska pornografii miał film, który wymagał znacznie mniejszego niż fotografia udziału wyobraźni. Zasadnicza różnica polegała jednak na tym, że zdjęcia zwykle odbierano prywatnie, natomiast film odtwarzany był w obecności szerszej widowni. Dlatego, jak stwierdza Lech M. Nijakowski, dla rozwoju pornografii filmowej kluczowe znaczenie miał stopień liberalizmu systemu prawnego $w$ danym kraju i swoboda obyczajowa ${ }^{40}$. Wraz z rozwojem kinematografii zaczął kształtować się system cenzury filmowej, także o charakterze obyczajowym ${ }^{41}$. Zauważa się także, że przekazy erotyczne, a zwłaszcza por-

35 Z. Wróbel, Erotyzm w literaturze nowożytnej, Krajowa Agencja Wydawnicza, Łódź 1987, passim; P. Krakowski, Z rozważań nad sztuka erotyczna, w: T. Hrankowska (red.), op. cit., s. 13-24; K. Jurecki, Między erotyzmem a pornografią. O sztuce amerykańskiej lat osiemdziesiątych i dziewięćdziesiątych, w: T. Hrankowska (red.), op. cit., s. 415-432; por. także: G. Bataille, Erotyzm, s. 217-258; D. de Rougemont, Miłość a świat kultury zachodniej, Pax, Warszawa 1968, s. 211-227.

36 J.R. Petersen, Stulecie seksu. Historia rewolucji seksualnej 1900-1999 według „Playboya”, Dom Wydawniczy Rebis, Poznań 2002, zwłaszcza s. 327-496.

37 B. McNair, Seks, demokratyzacja pożądania i media, czyli kultura obnażania, Muza, Warszawa 2004, s. 41 i n.; G. Bataille, Historia erotyzmu, s. 199 i n. Stwierdza się nawet, że: „Z męskiego punktu widzenia najprzyjemniejszym wątkiem w dziejach ludzkości jest ten dotyczący rozbierania się i ubierania kobiety. Zakrywanie i odkrywania ciała jest jednym z najprostszych i najbardziej ekscytujących działań ludzkości. Podniecające jest nie tylko to, co można zobaczyć, ale przede wszystkim to, co myślimy, że można zobaczyć" (zob. G. Sieczkowski, Cały ten seks. Kroniki podkasane, Baobab, Warszawa 2008, s. 1).

38 S. Sikora, Fotografia między dokumentem a symbolem, Instytut Sztuki PAN, Izabelin 2004, passim; L.M. Nijakowski, op. cit., s. 161-164.

39 M. Filar, Pornografia a sztuka, „Nowe Prawo” 1978, nr 10. Zob. także: B. Kunicka-Michalska, Pornografia i wykorzystywanie nieletnich w Internecie. Regulacje polskiego kodeksu karnego, „Studia Prawnicze” 2005, nr 4(166), s. 77-108.

40 Już w wilhelmińskich Niemczech przedstawienie nagiego ciała człowieka było całkowicie niedozwolone (L.M. Nijakowski, op. cit., s. 170).

41 W 1915 r. Sąd Najwyższy Stanów Zjednoczonych uznał, że film jest przedsięwzięciem o charakterze komercyjnym, a więc nie mają w stosunku do niego zastosowania przepisy stojące na straży wolności słowa. Pozwoliło to na działanie licznych komisji o charakterze cenzorskim, tworzenie kodeksów mających na celu ochronę moralności. Dopiero na kanwie sprawy z 1952 r. Burstyn przeciwko Wilson przyznano filmowi 
nograficzne, koncentrują się na pokazywaniu kobiety w stanie uniesienia, a celem pornografii nie jest zrozumienie źródła i natury tych uniesień ani ich przeżywania, lecz ich oswojenie ${ }^{42}$.

Dopiero ostatnio, wraz ze zmianą norm obyczajowych, wyzwoleniem kobiety z gorsetu konwenansów, powszechnego uznania jej jako podmiotu mającego prawo do seksualności, marzeń i oczekiwań seksualnych pojawiło się zjawisko przekazów pornograficznych wyraźnie adresowanych do kobiet ${ }^{43}$. Rola kobiety w społeczeństwie, jej prawo do przeżyć seksualnych ulegały w toku historii poważnym zmianom ${ }^{44}$. Przekazami erotycznymi, a może wręcz pornograficznymi, przesycone są liczne pisma adresowane do kobiet, chociażby takie jak „Cosmopolitan”, aczkolwiek nie ma periodyku, który zawierałby wyłącznie treści pornograficzne przeznaczone dla kobiet.

ochronę, odchodząc od koncepcji cenzury prewencyjnej. Ostatecznie jednak nastąpiło to w 1965 r. Od tej chwili przeciwnicy rozpowszechniania filmu muszą dowieść, że ma on charakter „obsceniczny”. Nadal jednak funkcjonuje system klasyfikacji filmów podobny do tego, który znany jest w Polsce w ustawie o radiofonii i telewizji. Zob. D.B. Sova, op. cit., s. 15.

42 Zob. A. Giddens, Przemiany intymności. Seksualność, miłość i erotyzm we współczesnych społeczeństwach, Wydawnictwo Naukowe PWN, Warszawa 2006, s. 146. Por. także: A. Moye, Pornography, w: A. Metcalf, M. Humphries (red.), The Sexuality of Men, Pluto Press, London - Sydney 1985, s. 68 i n.

43 „Pornografia wydawać się może niejednokrotnie bezsensowna w swoim wyuzdaniu, ale tak naprawdę u podstaw jest niezwykle racjonalna. Widoczna w jej obrębie specjalizacja, standaryzacja i schematyzm świadczą o tym dobitnie. Pornografia niczym szkło powiększające pokazuje ambiwalencję naszych czasów, rezygnację z kodeksów ugruntowanych religijnie bądź zwyczajowo, zasad na rzecz toczących się wciąż moralnych negocjacji. Pokazuje nasze marzenia o raju, w którym każdy żyje tak, jak chce, jak mu dyktuje serce, i równoczesną niemożliwość wyswobodzenia się z racjonalnego kieratu. Najważniejszą charakterystyką pornografii wcale nie jest jej nieracjonalność, a jedynie pragnienie, by taką być”. W. Klimczyk, op. cit., s. 138 i n. W literaturze zauważa się, że pornografia ma służyć zrozumieniu mechanizmu rozkoszy, i to rozkoszy kobiecej. Obsesyjne ukazywanie najrozmaitszych form aktu płciowego jest próbą rekonstrukcji logiki przyjemności. L. Williams, Hard Core. Power, Pleasure, and the „Frenzy of the Visible”, University of California Press, Berkeley 1989, s. 187. Por. także N. Prause, V.R. Steele, C. Staley, D. Sabatinelli, G. Hajcak, Modulation of late positive potentials by sexual images in problem users and controls inconsistent with "porn addiction”, „Biological Psychology" 2015, nr 109, s. 192-199.

44 W średniowieczu rozważano nawet, czy kobietę w ogóle można uznać za człowieka, zważywszy, że na podobieństwo Boga został stworzony Adam, a Ewa jedynie jako odwzorowanie Adama. Kobieta uważana była przez wieki za stworzenie nieczyste, skłonne do grzechu, zdradliwe, a więc niebezpieczne dla rodu. Żydzi dziękowali Bogu za to, że nie urodzili się kobietą, a w buddyzmie wcielenie wędrującej duszy w kobietę uważano za karę i degradację. W islamie wyraźnie wskazywano, że „mężczyźni mają pierwszeństwo nad kobietami, ponieważ Bóg dał im wyższość nad nimi” (por. M. Bogucka, Gorsza płeć. Kobieta w dziejach Europy od antyku po wiek XXI, Wydawnictwo Trio, Warszawa 2006, s. 29-35; K. Pytko, Pełna kontrola i kult dziewictwa. Dyskryminacja kobiet. Od zawsze. W każdej kulturze, „Focus”, 9.10.2018, https://www.focus.pl/ artykul/slaba-piekna-czy-gorsza-o-przypisanej-kobietom-roli [dostęp: 17.11.2018]; P. Brown, Ciało i społeczeństwo. Mężczyźni, kobiety i abstynencja seksualna we wczesnym chrześcijaństwie, Wydawnictwo Homini, Kraków 2006, s. 111-119; A. Kusiak, O historii kobiet, w: E. Pakszys, D. Sobczyńska (red.), Kobiety w poznaniu naukowym wczoraj i dziś, Wydawnictwo Naukowe UAM, Poznań 1997, s. 197-219; E. Pakszys, Feministyczna rewindykacja wobec nauk o życiu albo o roli płci/rodzaju w poznaniu biologicznym, w: E. Pakszys, D. Sobczyńska (red.), op. cit., s. 263-283; G.R. Taylor, Science of Life. A Picture History of Biology, Thames and Hudson, New York - Toronto 1963). 
Seksualizacja kultury związana z szeroką zmianą społeczną, będąca - jak stwierdza się w literaturze - pochodną przełomowych wynalazków technologicznych oraz nacisków komercjalnych, prowadzi m.in. do medialnej dostępności seksu, obscenicznego zainteresowania nagością, ekshibicjonizmu ${ }^{45}$. Środki społecznego przekazu tworzą kulturę, w której publiczna nagość, voyeuryzm są dozwolone. Epatują nagością nie tylko pisma uznawane za pornograficzne, lecz także te, które zaliczane są do czasopism poważnych, a nawet popularnonaukowych ${ }^{46}$. Podkreśla się, że w latach 90. XX w., „dotrzymując kroku postmodernistycznym nastrojom tej dekady, pornograficzna ikonografia w obfity sposób zamieszczała przyjemne erotyczne obrazki jako przedstawienia mody, a nie pornografii"47. Okazało się w tym czasie, że roznegliżowane modelki na okładkach i towarzyszące im „obiecujące”, przesycone erotyzmem zapowiedzi artykułów w sposób znakomity wpływają na zwiększenie sprzedaży czasopism. Dodać należy, że niejako przy okazji stwierdzono, iż odwoływanie się do nagości i seksu, czasem powiązanego z ironią i humorem, jest dobrym zabiegiem w reklamowaniu różnych towarów. Rozwój fotografii, a zwłaszcza fotografii cyfrowej, pozwalającej na daleko idącą manipulację, doprowadził do głębokich przemian społecznych, szczególnie w momencie, kiedy pozornie anonimowy, a w każdym rasie uchodzący za takowy, Internet pozwolił na masowe rozpowszechnianie tego typu zdjęć ${ }^{48}$. Warto zauważyć, że postrzeganie nagości nie jest niezależne od norm kulturowych. Interpretacja wizerunku nagiego człowieka zależy od punktu widzenia lub ram, jakie przyjmuje odbiorca. W literaturze wskazuje się, że mogą być to ramy sztuki, pornografii, informacji i reklamy. Istotą wydaje się być seksualizacja wstydu ${ }^{49}$.

\section{Wolność sztuki a zjawisko pornografii}

Koncepcja wolności sztuki ukształtowała się w toku rozwoju myśli filozoficznej o sztuce jako refleksja formułowana na polu estetyki. Łączono ją z aspektami formalnymi twórczości, którą wyznaczały pierwotnie kanony obrazowania. Samo pojęcie wolności sztuki zaadaptowano na potrzeby środowisk artystycznych, dą-

\footnotetext{
45 S. Morawski, Sztuka i pornografia, „Studia Socjologiczne” 1965, nr 4, s. 217.

46 Ważną datą dla problematyki pornografii było ukazanie się w 1953 r. pisma „Playboy”. J.R. Petersen, op. cit., passim. Zob. także B. McNair, Seks, demokratyzacja..., s. 5, 21.

47 B. McNair, Seks, demokratyzacja..., s. 159.

48 K. Olechnicki, Fotoblogi, pamiętniki z opcja przekazu. Fotografia i fotoblogerzy w kulturze konsumpcyjnej, Oficyna Wydawnicza Łośgraf, Warszawa 2009, s. 83-102; L. Manovich, Język nowych mediów, Wydawnictwa Akademickie, Oficyna Wydawnicza Łośgraf, Warszawa 2006, s. 124-127; B. Kunicka-Michalska, Przestępstwa przeciwko wolności seksualnej i obyczajności popełniane za pośrednictwem systemu informacyjnego, Zakład Narodowy im. Ossolińskich, Warszawa 2004, s. 89; Z. Lew-Starowicz, Seks w sieci i nie tylko, Wydawnictwo Medyczne, Kraków 2003, s. 58 in.

49 L.M. Nijakowski, op. cit., s. 328; B.A. Eck, Nudity and Framing: Classifying Art., Pornography, Information and Ambiguity, „Sociological Forum” 2001, vol. 16, nr 4, s. 604.
} 


\title{
ARTYKUtY
}

\author{
Jacek Sobczak
}

żących do wyzwolenia spod kontroli organizacji społecznych, zarówno państwa, jak i Kościoła i innych związków religijnych ${ }^{50}$.

Poza obrębem niniejszych rozważań należało pozostawić problem kontratypu sztuki, przywoływany zarówno przez badaczy, jak i artystów w sytuacjach, gdy przekaz artystyczny (obraz, inscenizacja, występ piosenkarza) może naruszać uczucia religijne. Na gruncie sporu odnoszącego się do tego, czy przekaz artystyczny nie jest jednocześnie pornografią lub czy takowy przekaz jest w ogóle sztuką, kwestia kontratypu sztuki nie była wykorzystywana ${ }^{51}$.

Odpowiadając na pytanie, czy sztuka może być pornografią i jakie są wzajemne relacje sztuki i pornografii, wypada przypomnieć, że funkcją normy prawnej nie jest dawanie definicji filozoficznych lub wybieranie między takimi definicjami, lecz ochrona bieżących interesów społecznych ${ }^{52}$. Tak więc generalna linia podziału między sztuką a pornografią przebiega między stoicką koncepcją sztuki jako imitacją natury, mającą pełnić funkcję wychowawczą, a koncepcją idealistyczno-epikurejską, ujmującą sztukę jako aktywność ducha, która pełni funkcję hedonistyczną. To przeciwstawienie musiało rodzić konflikt między treścią a formą. Doktryna chrześcijańska przejęła koncepcję stoicką, czyniąc ze sztuki funkcję religii i środek ekspresji dla gloryfikacji Boga. Rozwiązanie to przyjęły także świeckie teorie totalitarystyczne, głosząc hasła sztuki zaangażowanej. Koncepcja hedonistyczna nadal jednak jest żywa albo w rozwiązaniach odrodzenia, albo w koncepcjach romantycznych. Dla prawnika oznacza to konieczność albo uznania, że sztuka pozostaje poza sferą ocen moralnych, albo też, tak jak każdy inny rodzaj ludzkiej aktywności, podlega takim ocenom i sądom. W konsekwencji powoduje to konieczność przyjęcia albo teorii ontologicznego wyłączania sztuki i sprośności, albo teorię koegzystencji sztuki i sprośności. Według pierwszej z tych koncepcji, sztuka nie może być

\footnotetext{
50 M. Gołda-Sobczak, Reformacja wobec sztuki, w: T. Kononiuk, K. Seroka (red.), Idee reformacji w tradycji społeczno-politycznej od XVI do XXI wieku, Grupa Cogito, Warszawa 2018, s. 121 i n.

51 Zob. T. Gardocka, Czy w polskim prawie karnym potrzebny jest kontratyp sztuki?, „Palestra” 2015, z. 1-2, s. 24 i n.; M.M. Bieczyński, Pojęcie sztuki w niemieckiej literaturze prawniczej i orzecznictwie Niemieckiego Sadu Konstytucyjnego, Wydawnictwo Naukowe Scriptorium, Opole 2012, s. 17-72; J.J. Nalewajko, R. Kubiak, Sztuka jako okoliczność wyłązajaca bezprawność, „Palestra” 2000, nr 9-10, s. 9-10; J. Warylewski, Pasja czy obraza uczuć religijnych. Spór wokół art. 195 kodeksu karnego, w: L. Leszczyński, E. Skrętowicz, Z. Hołda (red.), W kręgu teorii i praktyki prawa karnego. Księga poświęcona pamięci prof. Andrzeja Wąka, Wydawnictwo Uniwersytetu Marii Curie-Skłodowskiej, Lublin 2005, s. 425-438; J. Piskorski, Kontratyp sztuki?, w: W. Szafrański (red.), Wokół problematyki prawnej zabytków i dzieł sztuki, t. 1, Wydawnictwo Poznańskie, Poznań 2007, s. 165; J. Sobczak, Kontratyp dozwolonej krytyki, w: M. Mozgawa (red.), Przestępstwa przeciwko czci i nietykalności cielesnej. IV Lubelskie Seminarium Karnistyczne, Wolters Kluwer Polska, Warszawa 2013, s. 250-312; A. Adler, What's left? Hate Speech, Pornography and the Problem for Artistic Expression, „California Law Review” 1996, vol. 8, nr 6, s. 1499; M. Bächli, Das Recht am eigenen Bild, Helbing \& Lichtenhahn, Basel - Genf - München 2002, s. 111; K. Schmoller, Strafrecht und die Freiheit der Kunst. Die Suche nach einer Grenze, w: D. Pauger (red.), Art goes Law. Dialoge zum Wechselspiel zwischen Kunst und Recht, Böhlau, Wien 2005, s. 203-208; H. Welzel, Das Deutsche Strafrecht. Eine systematische Darstellung, De Gruyter, Berlin 1969, s. 447.
}

52 M. Filar, Sztuka a zagadnienie pornografii, „Nowe Prawo” 1978, nr 10, s. 1432. 
sprośna, a więc nie może być pornografią. Tak więc dzieło pornograficzne nie jest sztuką. Zgodnie z drugą, dopuszczalna jest możliwość koegzystencji dzieła sztuki ze sprośnością. W konsekwencji istnieje konieczność rozstrzygnięcia kwestii odpowiedzialności karnej za stworzenie, posiadanie, rozpowszechnianie dzieła sztuki, które jest sprośne, a więc pornograficzne. Tej teorii zdaje się hołdować obecnie obowiązujący Kodeks karny, a także poprzedzające go kodyfikacje dotyczące odpowiedzialności karnej.

Z teorią ontologicznego wyłączania sztuki i sprośności współgra wychodząca z innych przesłanek filozoficznych teoria esencjonalnej moralności sztuki, funkcjonująca w kilku wariantach. W literaturze wyróżnia się teorię puryfikacji estetycznej, puryfikacji inspiracyjno-celowościowej i teorię adekwatności socjalnej ${ }^{53}$. Elementem decydującym o puryfikacji, czyli oczyszczeniu przekazu, jest formalno-estetyczny poziom dzieła, a więc taki, w którym wartość artystyczna jest niepodważalna (teoria puryfikacji estetycznej). Oddanie oceny formalno-estetycznego poziomu dzieła w ręce prawników nie jest jednak rozwiązaniem najszczęśliwszym. Według zwolenników puryfikacji inspiracyjno celowościowej, czynnikiem oczyszczającym jest inspiracja i zamiar autora. Docieczenie istnienia tego zamiaru wydaje się niezwykle trudne, jeśli nie wręcz niemożliwe. Według teorii adekwatności socjalnej, kryterium puryfikacyjnym jest to, że dzieło sztuki nie może naruszać dobra prawnego ${ }^{54}$. Tak więc ta teoria, sformułowana przez Angelo Raffaele Latagliatę, jest w gruncie rzeczy zgodna z teorią ontologicznego wyłączenia sztuki i sprośności.

Wspomniana wyżej teoria koegzystencji występuje w wariancie skrajnie moralistycznym bądź w teorii przewagi interesów. Pierwsza z tych koncepcji w przypadku występowania w dziele zarówno elementów artyzmu, jak i sprośności przy ostatecznej ocenie dawała bezwzględny prymat tym ostatnim. Wynikało to z przekonania, że wszystko, co sprośne, pornograficzne, nie może być nigdy uznane za dzieło sztuki. Koncepcja teorii przewagi interesów występowała bądź w wariancie absolutnego priorytetu sztuki, bądź w wariancie teorii oceny kwantytatywnej. W pierwszym z tych wariantów przekaz artystyczny ważniejszy jest od zawartych w nim elementów pornograficznych, a więc jeśli dzieło ma wartość artystyczną, to jego sprośność jest z natury rzeczy wyłączona. W wariancie kwantytatywnym koniecznością jest ilościowa analiza interesu społecznego, sprowadzającego się do zapewnienia swobody przepływu myśli i idei wyrażanych za pomocą przekazu artystycznego oraz interesu społecznego, polegającego na zakazie rozpowszechnienia przekazów pornograficznych. Odmianą teorii

\footnotetext{
53 Zob. ibidem, s. 1434, gdzie jest odwołanie do poglądów E. Battagliniego, L'arte e la tutela penale nel nuovo codice, „Rivista Penale” 1931, s. 462.

54 A.R. Latagliata, Atti osceni e atti contrari alla pubblica decenza, w: Enciclopedia del diritto, t. IV, Giuffre, Milano 1959, s. 64, cyt. za: M. Filar, Sztuka a zagadnienie..., s. 1436.
} 


\section{ARTYKUEY}

Jacek Sobczak

kwantytatywnej jest koncepcja dobra publicznego. W polskiej doktrynie prawniczej ta ostatnia koncepcja była dość popularna ${ }^{55}$.

Emocja estetyczna, jakiej doznaje się, obcując z dziełem sztuki, oglądając obraz czy czytając książkę, nie eliminuje innych emocji, w tym także emocji erotycznych. Niewątpliwie seks inspiruje twórców, zarówno wielkich pisarzy, jak i malarzy bądź figuratywnych rzeźbiarzy. W strofach Owidiusza, Rabelais'go, w Romeo i Julii Shakespeare'a, w Tristanie i Izoldzie, w Madame Bovary Gustava Flauberta, w niektórych fraszkach Jana Kochanowskiego, Ignacego Krasickiego, Kacpra Twardowskiego, w Dziejach grzechu i w Walce z szatanem Stefana Żeromskiego, w płótnach Rubensa, Boticellego, Tycjana, w Szale Władysława Podkowińskiego, w Mai nagiej Francisca Goi dopatrzeć by się można nie tylko erotyzmu, sprośności, ale przy odpowiednim nasileniu złej woli także pornografii.

\section{Wnioski}

Wypada w tym miejscu zastanowić się, czy istotnie państwo środkami karnymi winno zwalczać przekazy literackie bądź wizualne, kierując się jedynie tym, że w ich treści występuje opis stosunku seksualnego lub przedstawiona jest postać nagiej kobiety. Czy konieczne jest angażowanie organów ścigania i sądów w tym tylko celu, aby zadowolić garstkę, motywowanych najczęściej religijnie, polityków, duchownych czy działaczy społecznych dopatrujących się wszelkiego zła w nagiej postaci człowieka, w opisie aktu seksualnego bądź takowych pieszczot. Wydaje się, że na tak postawione pytania trzeba udzielić zdecydowanie odpowiedzi negatywnej, aczkolwiek przyznać należy, że przekaz pornograficzny może mieć i ma wpływ na rozwój psychofizyczny małoletniego. Nie do uniknięcia jest dzisiaj wpływ takiego przekazu na młodą osobę, podobnie jak było w przeszłości, kiedy ktoś zbyt wcześnie jak na swój wiek obejrzał jakieś obrazy czy przeczytał chociażby Chłopów Władysława Reymonta, Popioły Stefana Żeromskiego ze sceną gwałtu w tomie drugim, XIII księgę Pana Tadeusza czy nawet Krzyżowców Zofii Kossak.

Mimo obszernej literatury dotyczącej problemu pornografii i odpowiedzialności za przestępstwa seksualne, także w postaci rozpowszechniania pornografii, pozostaje nadal bez odpowiedzi kwestia stosunku sztuki do przekazu pornograficznego ${ }^{56}$. Za szczególnie niebezpieczne zjawisko wypada uznać przekazanie wydawania opinii, czy określony przekaz jest sztuką i czy jako sztuka wypełnia

55 Zwolennikiem tej teorii był A. Forel, Zagadnienia seksualne, [b.w.] Warszawa 1926, s. 140 oraz dopuszczający możliwość koegzystencji sztuki i pornografii L. Lernell, Przestępczość seksualna, w: K. Imieliński (red.), Seksuologia społeczna, Państwowe Wydawnictwo Naukowe, Warszawa 1977, s. 419, a także A. Osęka, Lament nad upadkiem pornografii, „Kultura” 1976, nr 31-33.

56 Zwrócić wypada uwagę na fakt, że nie ma jednej powszechnie obowiązującej i niebudzącej wątpliwości definicji sztuki. Zob. J. Sobczak, Wolność sztuki.., s. 360-370. W kwestii pojmowania sztuki w niemieckiej doktrynie prawnej zob. niezwykle ważne i świetnie udokumentowane wywody M.M. Bieczyńskiego, Pojęcie sztuki..., s. 17-72. Por. także M. Filar, Sztuka a zagadnienie..., s. 1432 in. 
znamiona pornografii, w ręce organów ścigania, a następnie sądów. Jednocześnie należy stwierdzić, że wytyczenie ścisłych granic sztuki, a także pornografii wydaje się być niemożliwe.

Wolność ekspresji artystycznej gwarantowana w polskim systemie prawnym wart. 73 Konstytucji, a kwestionowana w praktyce przez niektóre środowiska z różnych względów (religijnych, psychologicznych, etycznych bądź medycznych), łączy się z wolnością korzystania z dóbr kultury i zakazem tworzenia przez władze publiczne ograniczeń dostępu do takich dóbr. Tego rodzaju sytuacje skutkują dążeniami, aby przekazy oceniane przez jakąś osobę bądź grupę osób jako pornograficzne pozbawić przymiotu dzieła artystycznego, uznać za niemieszczące się w polu sztuki.

\section{Bibliografia}

Adler A., What's left? Hate Speech, Pornography and the Problem for Artistic Expression, „California Law Review" 1996, vol. 8, nr 6.

Bächli M., Das Recht am eigenen Bild, Helbing \& Lichtenhahn, Basel - Genf - München 2002.

Bataille G., Erotyzm, Wydawnictwo Słowo/obraz Terytoria, Gdańsk 1999.

Bataille G., Historia erotyzmu, Wydawnictwo Aletheia, Warszawa 2008.

Bataille G., Łzy Erosa, Wydawnictwo Słowo/obraz Terytoria, Gdańsk 2009.

Battaglini E., L'arte e la tutela penale nel nuovo codice, „Rivista Penale” 1931.

Bazin A., Ontologia obrazu fotograficznego, w: A. Bazin, Film i rzeczywistość, Wydawnictwa Artystyczne i Filmowe, Warszawa 1963.

Bieczyński M.M., Pojęcie sztuki w niemieckiej literaturze prawniczej i orzecznictwie Niemieckiego Saqdu Konstytucyjnego, Wydawnictwo Naukowe Scriptorium, Opole 2012.

Bogucka M., Gorsza płeć. Kobieta w dziejach Europy od antyku po wiek XXI, Wydawnictwo Trio, Warszawa 2006.

Bratuń M., Posłowie, w: D.A.F. de Sade, Justyna czyli nieszczęścia cnoty, Wydawnictwo Łódzkie, Łódź 1987.

Brown P., Ciało i społeczeństwo. Mężczyźni, kobiety i abstynencja seksualna we wczesnym chrześcijaństwie, Wydawnictwo Homini, Kraków 2006.

Budyn-Kulik M., Glosa do wyroku Sądu Najwyższego z dnia 23 listopada 2010 r., IV KK 173/10, LEX/el. 2011.

Decyzja Rady z dnia 29 maja 2000 r. w sprawie zwalczania pornografii dziecięcej w Internecie, Dz. Urz. UE L 138 z 9.06.2000, s. 1.

Dufour F.S.P., Historia prostytucji od czasów najdawniejszych do XX w., t. 1: Czasy przedchrześcijańskie, „Uraeus”, Gdynia 1997.

Dyrektywa Parlamentu Europejskiego i Rady 2011/92/UE z dnia 13 grudnia 2011 r. w sprawie zwalczania niegodziwego traktowania w celach seksualnych i wykorzystywania seksualnego dzieci oraz pornografii dziecięcej, zastępująca decyzję ramową Rady 2004/68/WsiSW, Dz. Urz. UE L 335 z 17.12.2011, s. 1.

Dyrektywa ramowa Rady 2004/68/WSiSW z dnia 22 grudnia 2003 r. dotycząca zwalczania seksualnego wykorzystywania dzieci i pornografii dziecięcej, Dz. Urz. UE L 13 z 20.01.2004, s. 44. 


\title{
ARTYKUtY
}

\author{
Jacek Sobczak
}

Eck B.A., Nudity and Framing: Classifying Art., Pornography, Information and Ambiguity, „Sociological Forum" 2001, vol. 16, nr 4.

Eco U. (red.), Historia piękna, Dom Wydawniczy Rebis, Poznań 2005.

Filar M., Pornografia a sztuka, „Nowe Prawo” 1978, nr 10.

Filar M., Pornografia, „Przegląd Ustawodawstwa Gospodarczego” 1993, nr 8-9.

Filar M., Pornografia. Studium z dziedziny polityki kryminalnej, Uniwersytet Mikołaja Kopernika w Toruniu, Toruń 1977.

Filar M., Przestępstwa seksualne w polskim prawie karnym, Uniwersytet Mikołaja Kopernika w Toruniu, Toruń 1985.

Filar M., Sztuka a zagadnienie pornografii, „Nowe Prawo” 1978, nr 10.

Filek B., Wizerunek nagiej osoby jako znamię przestępstwa z art. 191a § 1 k.k., „Prokuratura i Prawo" 2012, nr 7-8.

Forel A., Zagadnienia seksualne, [b.w.] Warszawa 1926.

Gardocka T., Czy w polskim prawie karnym potrzebny jest kontratyp sztuki?, „Palestra” 2015, z. 1-2.

Giddens A., Przemiany intymności. Seksualność, miłość i erotyzm we współczesnych społeczeństwach, Wydawnictwo Naukowe PWN, Warszawa 2006.

Gołda-Sobczak M., J Sobczak., Sztuka czy przekaz pornograficzny, w: M.M. Bieczyński, A. Jakubowski (red.), Prawo wobec erotyki w sztuce oraz pornografii, Wydawnictwo Silva Rerum, Wydawnictwo Uniwersytetu Artystycznego, Poznań 2016.

Gołda-Sobczak M., Reformacja wobec sztuki, w: T. Kononiuk, K. Seroka (red.), Idee reformacji w tradycji społeczno-politycznej od XVI do XXI wieku, Grupa Cogito, Warszawa 2018.

Jurecki K., Między erotyzmem a pornografią. O sztuce amerykańskiej lat osiemdziesiątych i dziewięćdziesiątych, w: T. Hrankowska (red.), Sztuka a erotyka. Materiały z Sesji Stowarzyszenia Historyków Sztuki, Łódź, listopad 1994, Arx Regia, Warszawa 1995.

Kirk J.R., Szkodliwość pornografii, Human Life International-Europa, Gdańsk 1998.

Klimczyk W., Erotyzm ponowoczesny, Towarzystwo Autorów i Wydawców Prac Naukowych Universitas, Kraków 2008.

Konwencja z dnia 12 września 1923 r. w sprawie zwalczania obiegu i handlu wydawnictwami pornograficznymi, ratyfikowana przez Polskę, Dz. U. z 1927 r. Nr 71, poz. 621.

Kosonoga J., Karnoprawna ochrona intymnego wizerunku osoby, „Studia i Analizy Sądu Najwyższego" 2011, t. V.

Krajewski R., Przestępstwo utrwalania i rozpowszechniania wizerunku osoby nagiej lub osoby w trakcie czynności seksualnej, „Prokuratura i Prawo” 2012, nr 5.

Krakowski P., Z rozważań nad sztuka erotyczna, w: T. Hrankowska (red.), Sztuka a erotyka. Materiały z Sesji Stowarzyszenia Historyków Sztuki, Łódź, listopad 1994, Arx Regia, Warszawa 1995.

Krawulska-Ptaszyńska A., Społeczne skutki upowszechnienia pornografii, „Ruch Prawniczy, Ekonomiczny i Socjologiczny" 1997, z. 1.

Kronhausen E. i P., Pornographie und Gesetz. Die Psychologie des erotischen Realismus u.d. Pornographie, Decker, Stuttgart 1963.

Kunicka-Michalska B., Pornografia i wykorzystywanie nieletnich w Internecie. Regulacje polskiego kodeksu karnego, „Studia Prawnicze” 2005, nr 4(166). 
Kunicka-Michalska B., Przestępstwa przeciwko wolności seksualnej i obyczajności popełniane za pośrednictwem systemu informacyjnego, Zakład Narodowy im. Ossolińskich, Warszawa 2004.

Kusiak A., O historii kobiet, w: E. Pakszys, D. Sobczyńska (red.), Kobiety w poznaniu naukowym wczoraj i dziś, Wydawnictwo Naukowe UAM, Poznań 1997.

Latagliata A.R., Atti osceni e atti contrari alla pubblica decenza, w: Enciclopedia del diritto, t. IV, Giuffre, Milano 1959.

Lernell L., Przestępczość seksualna, w: K. Imieliński (red.), Seksuologia społeczna, Państwowe Wydawnictwo Naukowe, Warszawa 1977.

Lew-Starowicz Z., Seks w sieci i nie tylko, Wydawnictwo Medyczne, Kraków 2003.

Lew-Starowicz Z., Seksuologia sadowa, Wydawnictwo Lekarskie PZWL, Warszawa 2000.

Lucie-Smith E., Erotism in Western Art, Oxford University Press, London 1972.

Manovich L., Język nowych mediów, Wydawnictwa Akademickie, Oficyna Wydawnicza Łośgraf, Warszawa 2006.

Maroń G., Pornografia. Próba sprecyzowania znaczenia terminu, „lus et Administratio” 2005, t. $4, \mathrm{nr} 8$.

Matuszewski K., Sade. Msza okrucieństwa, Wydawnictwo Słowo/obraz Terytoria, Gdańsk 2008.

McNair B., Mediated Sex. Pornography \& Postmodern Culture, Hodder Education Publishers, Londyn - Nowy Jork - Sydney - Auckland 1996.

McNair B., Seks, demokratyzacja pożądania i media, czyli kultura obnażania, Muza, Warszawa 2004.

Melosik Z., Ciało, tożsamość, władza. Teksty kulturowe jako konteksty pedagogiczne, Edytor, Poznań - Toruń 1996.

Michelson P., An Apology for Porn, w: A.H. Douglas (red.), Perspectives of Pornography, St. Martin's Press, New York 1970.

Mizielińska J., Płeć, ciało, seksualność. Od feminizmu do teorii queer, Towarzystwo Autorów i Wydawców Prac Naukowych Universitas, Kraków 2006.

Morawski S., Sztuka i pornografia, „Studia Socjologiczne” 1965, nr 4.

Moye A., Pornography, w: A. Metcalf, M. Humphries (red.), The Sexuality of Men, Pluto Press, London - Sydney 1985.

Mozgawa M., Przestępstwa przeciwko wolności, w: M. Mozgawa (red.), Kodeks karny. Praktyczny komentarz, Wolters Kluwer Polska, Warszawa 2010.

Nalewajko J.J., Kubiak R., Sztuka jako okoliczność wyłączająca bezprawność, „Palestra” 2000, nr 9-10.

Nijakowski L.M., Pornografia, historia znaczenie, gatunki, Wydawnictwo Iskry, Warszawa 2010.

Øistein Endsjø D., Seks a religia. Od balu dziewic po święty seks homoseksualny, Czarna Owca, Warszawa 2011.

Olechnicki K., Fotoblogi, pamiętniki z opcja przekazu. Fotografia i fotoblogerzy w kulturze konsumpcyjnej, Oficyna Wydawnicza Łośgraf, Warszawa 2009.

Osęka A., Lament nad upadkiem pornografii, „Kultura” 1976, nr 31-33. 


\title{
ARTYKUtY
}

\author{
Jacek Sobczak
}

Pakszys E., Feministyczna rewindykacje wobec nauk o życiu albo o roli płci/rodzaju w poznaniu biologicznym, w: E. Pakszys, D. Sobczyńska (red.), Kobiety w poznaniu naukowym wczoraj i dziś, Wydawnictwo Naukowe UAM, Poznań 1997.

Parker H.N., Love's body anatomized: the ancient erotic handbooks and the rhetoric of sexulity, w: A. Richlin (red.), Pornography and representation in Greece and Rome, Oxford University Press, Oxford, 1992.

Peiper L., Komentarz do kodeksu karnego, L. Frommer, Kraków 1936.

Petersen J.R., Stulecie seksu. Historia rewolucji seksualnej 1900-1999 według „Playboya”, Dom Wydawniczy Rebis, Poznań 2002.

Piskorski J., Kontratyp sztuki?, w: W. Szafrański (red.), Wokół problematyki prawnej zabytków i dziet sztuki, t. 1, Wydawnictwo Poznańskie, Poznań 2007.

Piwocki K., Dzieje sztuki w zarysie, t. 2: Od wieków średnich do końca XVII w., Arkady, Warszawa 1977.

Pornografia [hasło], w: M. Szymczak (red.), Słownik języka polskiego, t. 2, Warszawa 1988.

Pornografia [hasło], w: S. Dubisz (red.), Uniwersalny słownik języka polskiego, t. 3, Warszawa 2003.

Oświadczenie rządowe z 8 września 1922 r. w przedmiocie przystąpienia Rzeczypospolitej Polskiej do Międzynarodowego Porozumienia z dnia 18 maja 1904 roku i do Międzynarodowej Konwencji z dnia 4 maja 1910 roku, podpisanych w Paryżu, dotyczących zwalczania handlu żywym towarem, Dz. U. Nr 87, poz. 783 ze zm.

Prause N., Steele V.R., Staley C., Sabatinelli D., Hajcak G., Modulation of late positive potentials by sexual images in problem users and controls inconsistent with "porn addiction”, „Biological Psychology" 2015, nr 109.

Praz M., Zmysły, śmierć i diabeł w literaturze romantycznej, Wydawnictwo Słowo/obraz Terytoria, Gdańsk 2010.

Reinsberg C., Obyczaje seksualne starożytnych Greków, „Uraeus”, Gdynia 1998.

Rezolucja Rady i przedstawicieli rządów Państw Członkowskich zebranych w Radzie w dniu 17 lutego 1997 r. w sprawie nielegalnych i szkodliwych treści rozpowszechnianych w internecie, Dz. Urz. UE C 70 z 6.03.1997, s. 1.

Rougemont D. de, Miłość a świat kultury zachodniej, Pax, Warszawa 1968.

Saccasyn-Della Santa E., Les figures humaines du Paléolithique supérieur eurasiatique, De Sikkel, Anvers 1947.

Schmoller K., Strafrecht und die Freiheit der Kunst. Die Suche nach einer Grenze, w: D. Pauger (red.), Art goes Law. Dialoge zum Wechselspiel zwischen Kunst und Recht, Böhlau, Wien 2005.

Shattuck R., Wiedza zakazana. Od Prometeusza do pornografii, Towarzystwo Autorów i Wydawców Prac Naukowych „Universitas”, Kraków 1999.

Sieczkowski G., Cały ten seks. Kroniki podkasane, Baobab, Warszawa 2008.

Siewierski M., w: J. Bafia, K. Mioduski, M. Siewierski, Kodeks karny. Komentarz, wyd. 3, Wydawnictwo Prawnicze, Warszawa 1987.

Sikora S., Fotografia między dokumentem a symbolem, Instytut Sztuki PAN, Izabelin 2004.

Sobczak J., Gołda-Sobczak M., Prawo do informacji a utrwalanie wizerunku osoby nagiej bez jej zgody, w: J. Sobczak, W. Machura (red.), Etyka w mediach, vol. 8: Kodyfikacja czy modyfikacja norm, Wydawnictwo Naukowe Scriptorium, Poznań - Opole 2011. 
Sobczak J., Kontratyp dozwolonej krytyki, w: M. Mozgawa (red.), Przestępstwa przeciwko czci i nietykalności cielesnej. IV Lubelskie Seminarium Karnistyczne, Wolters Kluwer Polska, Warszawa 2013.

Sobczak J., Wolność ekspresji artystycznej. Regulacje europejskie a rozwiązania polskiego systemu prawnego, „Czasopismo Prawno-Historyczne” 2016, t. 68, z. 2.

Sobczak J., Wolność sztuki, twórczości artystycznej, satyry. Czy istnieje kontratyp sztuki? Regulacje europejskie a rozwiązania polskiego systemu prawnego, w: J. Jaskiernia (red.), Uniwersalny i regionalny wymiar praw człowieka. Nowe wyzwania - nowe rozwiqzania, t. 3, Wydawnictwo Sejmowe, OWG, Warszawa 2014.

Sontag S., The Pornografic Imagination, w: S. Sontag, The Pornografic Imagination, w: S. Sontag, Styles of Radical Will?, Dell, New York 1969.

Sova D.B., 125 zakazanych filmów. Historia cenzury w kinie, Świat Książki, Warszawa 2006.

Sprostowanie do dyrektywy Parlamentu Europejskiego i Rady 2011/92/UE z dnia 13 grudnia 2011 r. w sprawie zwalczania niegodziwego traktowania w celach seksualnych i wykorzystywania seksualnego dzieci oraz pornografii dziecięcej, zastępującej decyzję ramową Rady 2004/68/WSiSW, Dz.U. L 18 z 21.01.2012.

Ślęzak I., Seks i erotyka w sieci, czyli czego poszukują internauci, w: M. Sokołowski (red.), Oblicza Internetu. Opus Universale. Kulturowe, edukacyjne i technologiczne przestrzenie Internetu, Wydawnictwo Państwowej Wyższej Szkoły Zawodowej, Elbląg 2008.

Śliwiński S., Prawo karne materialne. Część szczególna, wyd. 2, [b.w.] Warszawa 1948.

Tannahill R., Historia seksu, Wydawnictwo Aletheia, Warszawa 2013.

Taylor G.R., Science of Life. A Picture History of Biology, Thames and Hudson, New York - Toronto 1963.

Ustawa z dnia 19 kwietnia 1969 r. Kodeks karny, Dz.U. Nr 13, poz. 94 ze zm.

Ustawa z dnia 6 czerwca 1997 r. Kodeks karny, tekst jedn. Dz. U. z 2016 r., poz. 1137 ze zm.

Ustawa z dnia 4 kwietnia 2014 r. o zmianie ustawy Kodeks karny oraz niektórych innych ustaw, Dz.U. poz. 538.

Warylewski J., Pasja czy obraza uczuć religijnych. Spór wokół art. 195 kodeksu karnego, w: L. Leszczyński, E. Skrętowicz, Z. Hołda (red.), W kręgu teorii i praktyki prawa karnego. Księga poświęcona pamięci prof. Andrzeja Wąska, Wydawnictwo Uniwersytetu Marii Curie-Skłodowskiej, Lublin 2005.

Warylewski J., Pornografia - próba definicji, w: M. Mozgawa (red.), Pornografia, Wolters Kluwer Polska, Warszawa 2011.

Warylewski J., Pornografia, w: J. Warylewski (red.), Przestępstwa przeciwko dobrom indywidualnym, C.H. Beck, Instytut Nauk Prawnych PAN, Warszawa 2012.

Warylewski J., Przestępstwa przeciwko wolności seksualnej i obyczajności. Rozdział XXV Kodeksu karnego. Komentarz, C.H. Beck, Warszawa 2001.

Warylewski J., Przestępstwa seksualne, Wydawnictwo Uniwersytetu Gdańskiego, Gdańsk 2001.

Warylewski J., Sprośne rysunki, w: J. Zajadło (red.), Fascynujące ścieżki filozofii prawa, Lexis-Nexis, Warszawa 2008.

Warylewski J., Uwagi do art. 202 k.k., w: A. Wąsek, R. Zawłocki (red.), Kodeks karny. Część szczególna, t. 1: Komentarz do art. 117-221, wyd. 4, C.H. Beck, Warszawa 2010.

Warylewski J., w: R.A. Stefański (red.), Kodeks karny. Komentarz, wyd. 2, Warszawa 2015. 


\section{ARTYKUŁY}

Jacek Sobczak

Welzel H., Das Deutsche Strafrecht. Eine systematische Darstellung, De Gruyter, Berlin 1969.

Williams L., Hard Core. Power, Pleasure, and the „Frenzy of the Visible”, University of California Press, Berkeley 1989.

Williams L., Hard Core. Władza, przyjemność i „szaleństwo widzialności”, Wydawnictwo Słowo/ obraz Terytoria, Gdańsk 2010.

Williams L., Seks na ekranie, Wydawnictwo Słowo/obraz Terytoria, Gdańsk 2013.

Wróbel W., Opinia prawna o rządowym projekcie ustawy o zmianie ustawy - Kodeks karny, ustawy - Kodeks postępowania karnego, ustawy - Kodeks karny wykonawczy, ustawy - Kodeks karny skarbowy oraz niektórych innych ustaw, Warszawa 28.01.2009 r., druk sejmowy nr 1394.

Wróbel Z., Erotyzm w literaturze nowożytnej, Krajowa Agencja Wydawnicza, Łódź 1987.

Wspólne działanie Rady 96/700/WSiSW z dnia 29 listopada 1996 r. ustanawiające program zachęty i wymiany dla osób odpowiedzialnych za zwalczanie handlu ludźmi i wykorzystywanie seksualne dzieci, Dz. Urz. UE L 322 z 12.12.1996, s. 7.

Wspólne działanie Rady 97/154/WSiSW z dnia 24 lutego 1997 r. przyjęte przez Radę na podstawie art. K. 3 Traktatu o Unii Europejskiej dotyczącego działań mających na celu zwalczanie handlu ludźmi i seksualnego wykorzystywania dzieci, Dz. Urz. UE L 63 z 4.03.1997, s. 2.

Wyrok Sądu Najwyższego z dnia 23 listopada 2010 r., sygn. akt IV KK 173/10, LEX nr 667510.

Zalecenie Rady 98/560/WE z dnia 24 września 1998 r. w sprawie rozwoju konkurencyjności europejskiego przemysłu usług audiowizualnych i informacyjnych przez wspieranie krajowych programów ramowych w celu zapewnienia skutecznego i porównywalnego poziomu ochrony nieletnich i godności ludzkiej, Dz. Urz. UE L 270 z 7.10.1998, s. 48. 